\title{
Roles of Biology, Chemistry, and Physics in Soil Macroaggregate Forma- tion and Stabilization
}

\author{
Kristine A. Nichols ${ }^{*}$ and Jonathan J. Halvorson
}

TheCan Caesar-TonThat USDA, Agricultural Research Service, Northern Great Plains Research Laboratory, 1701 10th Ave. SW, P.O. Box 459, Mandan, ND 58554, USA

\begin{abstract}
Many soil functions depend on the distribution of macro- $(\geq 0.25 \mathrm{~mm})$ and micro- $(<0.25 \mathrm{~mm})$ aggregates and open space between aggregates (i.e. soil structure). Despite the importance of macroaggregates in soil, little is understood about how they form and become stable. We hypothesize that biological activities, chemical reactions, and physical forces which help to form macroaggregates differ from those involved in stabilization. Formation is a binding process where aggregate components are brought spatially closer together, 'bagged' or enmeshed by roots and fungal hyphae and 'glued' by labile SOM. Stabilization involves bonding processes between organic matter, clay minerals, cations, or plant or microbial biomolecules which increase internal cohesiveness. By separating aggregate formation from stabilization, the biological, chemical, and physical processes involved in maintaining long-term soil quality through stabilized soil structure will be more easily identified.
\end{abstract}

Keywords: macroaggregate formation, macroaggregate stabilization, microbial exudates, root exudates, agronomic management, chemical bonding, physical forces.

\section{INTRODUCTION}

To support a growing global population in the near future, agricultural production needs to more than double under declining resources of land, fresh water, synthetic nutrients, and pesticides [1,2]. To accomplish this, sustainable intensification, or obtaining more output from the same land area while reducing the negative environmental impacts and increasing contributions to environmental services $[3,4]$ must be applied. By maximizing the efficiencies of the micro- and macro-functions across the entire system, this level of intensification may be achieved. In the soil, aggregation links micro-processes into a macro-component which is important for soil health, because aggregation provides soil structure, or the arrangement of open and closed spaces. Good soil structure provides better water and gas movement into, throughout, and out of soil; reduces run-off, erosion, and compaction; and improves nutrient cycling, soil carbon storage, and biological activities $[2,5,6]$.

Soil aggregates may be divided into macro- $(\geq 0.25 \mathrm{~mm})$ and micro- $(<0.25 \mathrm{~mm})$ aggregates, but it is the size and stability of the aggregates which primarily dictate the sizes and continuity of the pores with macroaggregates creating larger openings $[6,7]$. Therefore, macroaggregates (referred to hereafter as macroaggregates or aggregates) will be the

*Address correspondence to this author at the USDA, Agricultural Research Service, Northern Great Plains Research Laboratory, 1701 10th Ave. SW, P.O. Box 459, Mandan, ND 58554; Tel: 701-667-3008; Fax: 701-667-3054; E-mails: Kristine.nichols@ars.usda.gov; glomalin1972@gmail.com focus of this review. Identifying the biological activities, chemical reactions, and physical forces involved in macroaggregate formation and stabilization will assist agriculturalists in identifying management tools to use to maintain and possibly improve soil functions $[2,8]$.

Macroaggregates are comprised of soil components such as sand, silt, and clay primary particles; plant or microbial debris [i.e. particulate organic matter (POM)] and biomolecules; roots; fungal hyphae; and bacteria bound together in a conglomeration (Fig. 1) where intra-aggregate cohesiveness is stronger than any external or internal disruptive forces [8-11]. Miller et al. [12] described this as a 'sticky string bag' process where networks of fine roots and mycorrhizal hyphae create a 'bag' or net to enmesh microaggregates and soil components (Fig. 2) which are 'stuck' to this 'bag' by root and microbial exudates (Fig. 1). Because the first part of this process describes how soil components are placed spatially closer together and the second part involves labile and water-soluble 'glues', this description of aggregation mainly addresses aggregate formation and not the main components which convey stability $[13,14]$. Usually, macroaggregate formation occurs before stabilization, but sometimes the stabilization of aggregate components initiates aggregate formation or these processes occur simultaneously $[6,15]$. In addition, the transient, temporary, or resistant agents involved in both processes may be indistinguishable $[11,12]$.

There are no standard methodologies for measuring aggregation, and different researchers use a wide variety of indices which apply diverse methodologies for drying soil, dry-sieving aggregates, and measuring aggregate stability 


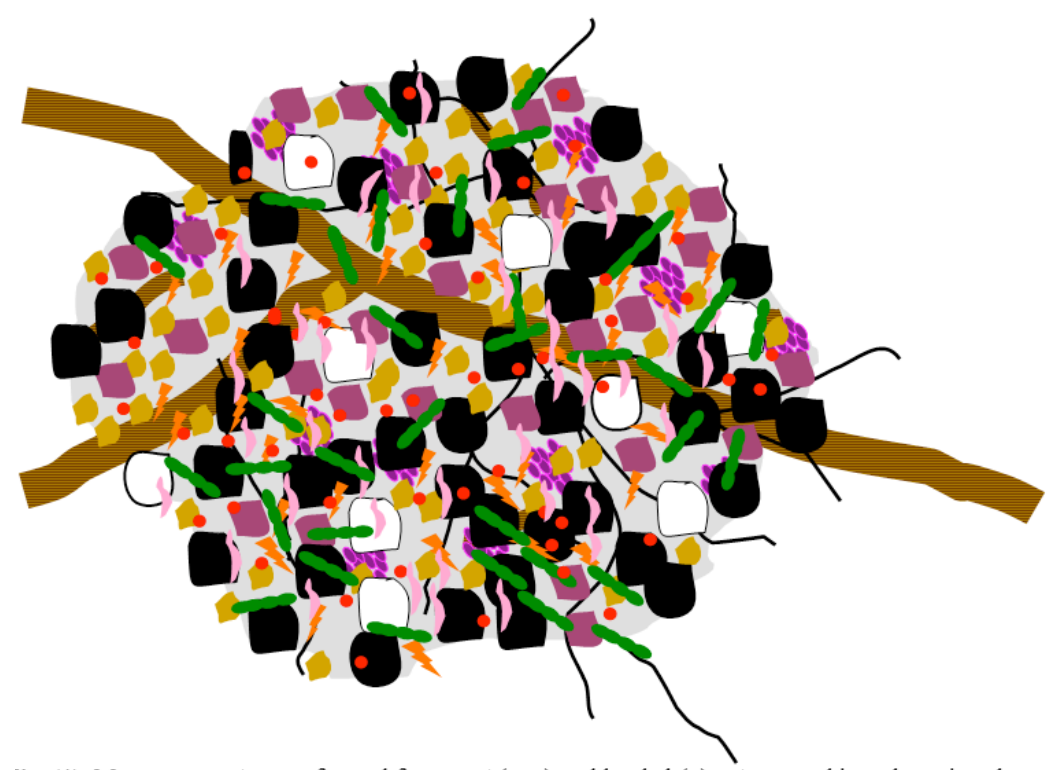

Fig. (1). Macroaggregates are formed from root $(\boldsymbol{\mathcal { N }})$ and hyphal $(\boldsymbol{N})$ nets enmeshing clay minerals $(\boldsymbol{)})$ silt particles $(\boldsymbol{D})$, sand $(\mathbf{O})$, particulate organic matter ( $)$, decomposed organic matter ( $)$, and bacterial colonies (8). Sticky root exudates and microbial biomolecules, such as sugars and polysaccharides ( ), glue macroaggregates together which are then stabilized by waxy microbial biomolecules, like glomalin, hydrophobins, or biofilms ( - , and organo-mineral complexes formed between clay minerals, organic matter, and/or polyvalent cations ( $)$.
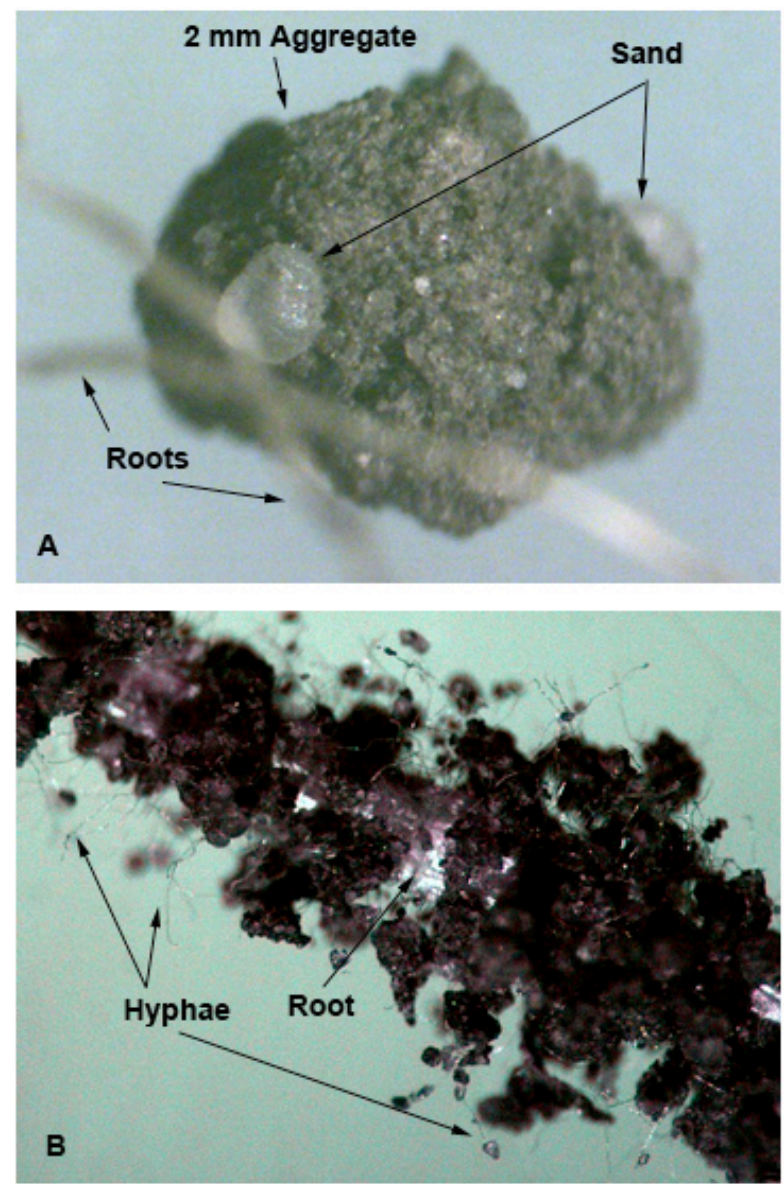

Fig. (2). Macroaggregates formed quickly (about 50-60 days) around hyphal nets extending out from big bluestem (Andropogon geradii) roots in a pot culture study with a 1:1 sand:soil mix (A) and from a Proso millet (Panicum miliaceum) root collected from a crover crop mixture which was planted following forage pea (Pisum sativum L. subs. Sativum var. arvense) harvest in a Parshall fine sandy loam (coareloamy, mixed superactive, frigid, Pachic Haplustolls) soil at a farm near Bismarck, ND, USA (B). 
Table 1. The Most Common Parameters and Techniques used for Evaluating Soil Aggregation

\begin{tabular}{|c|c|c|c|}
\hline Drying Soil & Dry Sieving Aggregates & Wet Sieving & Indices \\
\hline \hline Air-drying & Manual tapping single sieves & $\begin{array}{c}\text { Yoder method of mechanically moving stacked } \\
\text { sieves up and down in a column of water }\end{array}$ & Mean weight diameter [81] \\
\hline Oven drying at $70^{\circ} \mathrm{C}$ & Mechanical shaking single sieves & $\begin{array}{c}\text { Manually moving stacked or single sieves up and } \\
\text { down in a column of water }\end{array}$ & Geometric mean diameter [81] \\
\hline Oven drying at $105^{\circ} \mathrm{C}$ & Mechanical shaking stacked sieves & $\begin{array}{c}\text { Mechanically moving single sieves up and down } \\
\text { in a column of water }\end{array}$ & Normalized Stability Index [16] \\
\hline & Rotary sieve with stacked sieves & Aggregate Stability Index [81] \\
\hline & & & Water-Stable Aggregation [21] \\
\hline & & & Whole Soil Stability Index [17] \\
\hline
\end{tabular}

\section{Formed Aggregates \\ gates} weighed and placed in a sieve.

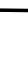

(2)

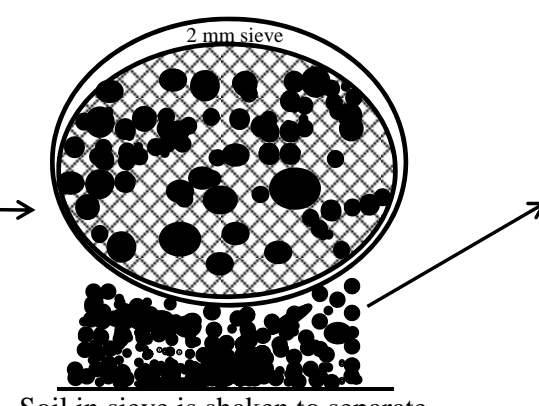

Soil in sieve is shaken to separate out material which passes through the screen. This material is then placed on a screen with a smaller mesh size.

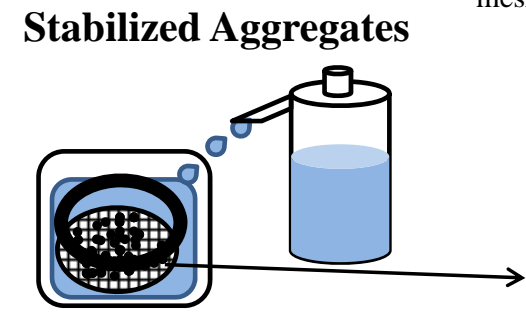

A subsample of aggregates collected above is placed in sieve with water added around the outside so it moves into the aggregates by capillary action.

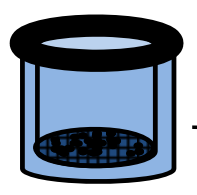

The sieve is place in a jar filled with water and mechanically moved up and down for five minutes.

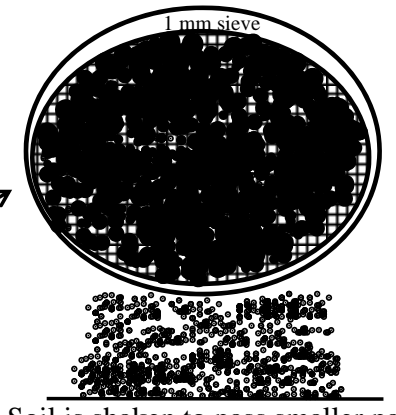

Soil is shaken to pass smaller particles through the screen. Aggregates remaining on top of the screen are collected while the particles passing through the screen are transferred to the next smaller sieve.

Fig. (3). Aggregation formation is quantified by weighing air-dried aggregates which pass through a series of screens. Aggregates stabilization is quantified by wet-sieving the formed aggregates and subtracting the coarse material (i.e. particulate organic matter and sand which are the same size as the aggregates) weight from the stabilized aggregate's weight.

(Table 1) [16]. Macroaggregate size classes, or the range of aggregates separated from the soil by passing soil through a series of screens differs from 10-0.25 mm among studies. In this review, we reference the method described by Nichols and Toro [17] for measuring the whole soil stability index (WSSI). This methodology was chosen because the WSSI allows dry aggregates (i.e. aggregates formed in soil) to be quantified separately as aggregates collected by dry sieving from the water-stability of these aggregates (i.e. aggregate stabilization) (Fig. 3). In this method, dried soil is passed through a series of screens from the largest to the smallest with the aggregate size class (ASC) identified as those particles passing through a screen and collected on the next smaller screen. The weight of aggregates collected in each ASC is compared to the bulk soil weight to determine the dry aggregate size distribution (DASD) [2, 14, 17-20]. Aggregate stabilization is measured via the water-stable aggregation (WSA) test described by Kemper and Rosenau [7, 10, 21]. Stable aggregates are those remaining on the screen after mechanical wet-sievingand correcting for coarse material (i.e. POM and sand which may be of the same size as that of aggregates) [19, 21].

Although examining aggregate formation separately from aggregate stabilization is not entirely novel, the authors feel that separating these concepts will help future research iso- 
late the biological, chemical and physical processes involved. This will assist in identifying management techniques which will improve long-term soil quality and increase soil carbon sequestration. The remainder of this review will focus on the biological activities, chemical reactions, and physical forces involved in aggregate formation, aggregate stabilization, or both. In addition, the impacts of aboveground management practices on these biological, chemical, and physical processes will be described.

\section{BIOLOGICAL CONSTITUENTS}

Macro- and microscopic organisms in and on the soil such as plants, grazing and burrowing animals, earthworms, insects, fungi, and bacteria play roles in aggregate formation and stabilization. The movements of the organisms themselves may change the spatial distribution of soil components while biological constituents, including POM, roots, fungal hyphae, and microbial biomolecules, impact the soil environment chemically and physically. In addition, the bodies, exudates, and waste products of these organisms act in aggregate formation or stabilization or as substrates for further chemical reactions. In many cases, biological activities involve chemical reactions or physical forces, but since the chemical or physical components are initiated by biological activities, they will be discussed in this section whereas chemical reactions or physical forces which involve abiotic components or are almost strictly physical, such as the movement of organisms will be discussed in those sections.

\section{Soil Organic Matter (SOM)}

More than $2300 \mathrm{Pg}$ of $\mathrm{C}$ are found in different SOM fractions, ranging from POM, which may be shredded plant or animal debris that looks similar to its original state, to humin and from biomolecules, like sugars and proteins, to the bodies of microorganisms [22]. Based on their molecular structure and decomposition rates, SOM fractions range from temporary (i.e. decomposable), transient (i.e. partially decomposed or somewhat physically- or chemically-stabilized), and resistant (i.e. highly decomposed or physically- or chemically-stabilized) and may play different roles in aggregate formation and stabilization [7, 23-25]. Typically, it is temporary or transient agents that provide the framework and 'glue' used in aggregate formation while the physically- or chemically-stabilized or resistant organic matter (OM) conveys stability.

Aggregates are formed by temporary and transient compounds, such as sugars, organic acids, polysaccharides, and proteins in plant and microbial exudates, because they contain sticky carboxyl $(\mathrm{COOH})$ and carbonyl $(\mathrm{C}=\mathrm{O})$ groups. These molecular groups also make these compounds watersoluble (i.e. polar) and easily decomposable, but solubilization or decomposition may cause the aggregate to fall apart $[22,26]$. To maintain aggregate structure, these compounds may be continuously replaced or become chemically- or physically-stabilized within the aggregate.

Modifications to the molecular structure or chemical or physical stabilization may convert temporary compounds into transient or resistant compounds which has made attempts to model SOM decomposition rates and aggregate stability difficult $[22,25]$. Molecular modifications, such as polymerization or chemically-binding to other molecules, atoms, or minerals, may change the $3 \mathrm{D}$ conformation by creating longer chains or a more complex structure such as organomineral complexes which resist enzymatic decomposition. Aggregate-occluded SOM has a slower decomposition rate and is present in higher concentrations than SOM free in the soil due to physical stabilization by exclusion of larger organisms, such as microarthropods, from intraaggregate pores [14, 27-29]. Intra-aggregate pore size (i.e. pore exclusion principle), oxygen-levels, and inhibition signals between organisms also may limit the type of substrate consumed and the distribution and colony size of microorganisms which impact decomposition rate [16, 22, 23].

Plant or microbial exudates and POM undergo several levels of decomposition in the transition from temporary to resistant compounds. Enzymatic decomposition of carboxyls and carbonyls leaves waste products which are more aliphatic $(\mathrm{C}-\mathrm{H})$ and non-polar as they are decomposed through members of the soil food web. Eventually this material becomes 'humified' into highly resistant OM [23, 29, 30]. Resistant compounds usually are comprised of aliphatic (C-H) (i.e. nonpolar) or aromatic (i.e. cyclical) groups $[22,23,31$, 32]. In addition, to becoming stabilized by partial enzymatic decomposition, labile OM may become stabilized in the guts of macrofauna where it is mixed with clay minerals and metals [23] and may be protected from further decomposition. This protected-OM may act as nucleating agents for aggregate formation as the chemical binding capabilities of claycoated $\mathrm{OM}$ are high.

\section{Plant Roots and Fungal Hyphae}

Growth of plant roots and fungal hyphae along with the movements of soil organisms such as earthworms, insects, and burrowing animals may translocate SOM constituents or exert physical forces on the soil environment which can assist in aggregate formation and stabilization [33,34]. The physical forces are axial and radial pressures which may cause compaction or cracking in the surrounding soil and may move aggregate forming agents into closer proximity or destabilize soil aggregates. These forces will be discussed in more detail in the physical forces section.

Soil is defined as a natural body consisting of sand, silt, and clay primary particles and SOM. Before plants and animals began colonizing land, soil did not exist because land was comprised of inorganic components and did not include SOM. Early in the evolution of land plants, roots were not absorptive structures but rather acted to anchor the plant in place [35]. To survive in this environment, plants evolved a relationship with arbuscular mycorrhizal (AM) fungi where the fungus absorbs water and nutrients and exchanges them for photosynthetically-derived carbon [36, 37]. Arbuscular mycorrhizal fungal hyphae have a small diameter and a large surface area for absorption. In this early earth environment, forming soil and soil structure (a form of habitat engineering) would be advantageous to plant health because $\mathrm{OM}$ holds nutrients in place, feeds microbes which release nutrients bound to minerals, and creates pore space for water movement and gas exchange [23, 38, 39].

In addition, the hyphae of a russuloid basidiomycete fungus isolated from a crop field near Sidney, MT, USA have been shown to be strongly related to increases in aggregate formation [40]. In an experiment, basidiomycete mycelium 
was mixed with sandy soil and 5\% millet or lentil straw. Water-stable aggregates started forming after one week with $100 \%$ of the aggregates formed being stabilized at four weeks' time. However, after four weeks, stability started to decline coinciding with reduced substrate (i.e. residue) availability. This experiment showed how tightly coupled Cavailability is to aggregate formation and stability making the role of this fungus seasonal and short-lived [40].

\section{Microbial Biomolecules}

Fungi and bacteria produce a variety of extracellular polymorphic substances (EPS) such as (glyco) proteins, glycans, glucans, polysaccharides, lipids, lipoproteins, and pigments $[8,22,23]$. The energy to create and the $\mathrm{C}$ backbone of EPS comes from carbon either directly or indirectly from plants [41]. Some of these biomolecules contain monosaccharides (i.e. sugar moieties which are the 'sticky' glues that form aggregates). Other biomolecules contain hydrophobic groups or form complex, polymeric structure consisting of proteins, polysaccharides, or fatty acids. These other molecules may stabilize aggregates by coating the aggregate surface and/or intra-aggregate pores with protective films similar to the way these molecules protect fungal hyphae or bacterial colonies from differing turgor pressures at air-water interfaces $[42,43]$.

Fungally-secreted biomolecules include scleroglucan, hydrophobins, glomalin, and mucilages such as the one produced by the russuloid basidiomycete discussed above. In addition, hyphal cell walls may consist of layers of biomolecules: $\alpha-1,3$ and $\alpha-1,6$ glucans, glycoproteins, proteins, or chitin microfibrils. As hyphae ramify through soil containing air- or water-filled pore space, EPS and cell wall components slough off the growing tip and attach themselves to the surrounding soil $[43,44]$. In the soil, these molecules form ionic and hydrogen bonds with clay minerals to create organo-mineral complexes [45]. These biomolecules also act as energy sources for bacteria in the hyphosphere, or the zone of intense microbial activity around the hyphae [40, 46]. One example of a bacterium found in the hyphosphere is Bacillus subtilis which solubilizes minerally-bound phosphorus for mycorrhizal uptake [47]. Although the mechanisms behind syntheses and deposition of fungal biomolecules are still poorly understood, they play roles in: (a) adhesion; (b) protection against desiccation, freezing, and water potential fluctuations; (c) buffering between cells and toxic environments [43]; and (d) initiating aggregate formation and stabilization (Figs. 1 and 2) [6, 12].

Scleroglucan is a polysaccharide produced by species of Sclerotium fungi which increases the stability of both kaolinitic and montmorillonitic clays forming organomineral complexes, which may act as nucleating agents for aggregate formation [8, 48, 49]. Hydrophobins are a family of surfaceactive, small fungal proteins (ca. 100 amino acids) which have amphiphilic, or hydrophobic and hydrophilic character [43]. Many ectomycorrhizal fungi produce hydrophobins which function at air-water interfaces and allow fungal hyphae and spores to withstand differing osmotic pressures [43, 50]. These proteins may form rod like shapes which can selfassemble into amphiphilic surface films [51, 52]. The russuloid basidiomycete produces copious amounts of fucosyl sugar-containing extracellular materials to create a mucilage with adhesive properties [45]. Production of this mucilage is dependent upon residue concentration. As residue declines, mucilage production declines. Also, because this mucilage is monosaccharide based, it is easily decomposed, and without a continual input of residue may lead to aggregate destabilization.

Microscopic images in the late 80's and early 90's revealed the presence of an amorphous material covering AM fungal hyphae $[11,53]$. This substance was classified as a polysaccharide. However, later research found an immunoreactive substance, called glomalin, on AM fungal hyphae which reacts with monoclonal antibody and is glycoproteinaceous [54]. Subsequent research has found glomalin to be located in the cell walls of arbuscular-mycorrhizal fungi and is genetically similar to heat shock proteins [55-57]. The hyphal wall represents an interface to the soil environment making glomalin a biomolecule involved in interactions, such as hyphal attachment, nutrient acquisition, and defense, with other soil biota and soil surfaces $[55,56,58]$

Glomalin is operationally-defined as proteinaceous materials extracted from soil with alkaline sodium citrate [54] or pyrophosphate [59] at an elevated temperature $\left(121^{\circ} \mathrm{C}\right)$ in multiple hour-long extraction periods. Other research has shown that the alkaline solution and prolonged heat are effective in breaking the bond between clay minerals and organic polymers, but this is not a highly specific extraction and the extract solution may contain other substances such as tannins and humic compounds [11]. However, the immunofluorence procedure, using an anti-glomalin monoclonal antibody, does indicate that glomalin is an AM fungally-produced substance since it has been found on AM colonized roots and fungal hyphae grown in a sterilized sand media and using sterilized seeds and fungal spores and in sterile root-organ cultures (Fig. 4) [46]. A monoclonal antibody has been used via enzyme-linked immunosorbent assays (ELISA) to quantify glomalin in the non-specific alkaline extract solution with mixed results even though all the extractants contain some immune-reactive material. Therefore, although the material collected during the extraction procedure may not be entirely $\mathrm{AM}$ in origin, the glomalin fraction does represent an important SOM fraction which has been widely linked with soil aggregation [60-64].

As a glycoprotein, glomalin has oligosaccharides or glycans bonded to a protein. Glycans are typically found on the outer surface of a glycoprotein and are involved in cell-cell or cell-matrix interactions mainly in an aqueous medium [65]. The protein component may contain hydrophobic amino acids which are typically folded into the interior of the protein $3 \mathrm{D}$ structure. In a hydrophobic or amphiphilic medium, the protein will refold to put the glycans in the center of the 3D structure. By folding and refolding, a glycoprotein is able to maintain the most energetically-stable $3 \mathrm{D}$ configuration, and to function at interfaces [65]. These changes in conformation may also assist glomalin in acting as a 'glue' in aggregate formation or as a hydrophobic coating on the intra-aggregate surface for aggregate stabilization [44]. Preliminary research has indicated that glomalin has similar characteristics as hydrophobins or other fungal biomolecules. Nuclear magnetic resonance (NMR) studies showed that glomalin is high in aliphatic, hydrophobic $\mathrm{C}-\mathrm{H}$ chains [44, 66, 67]. In soil, glomalin appears to slough off 

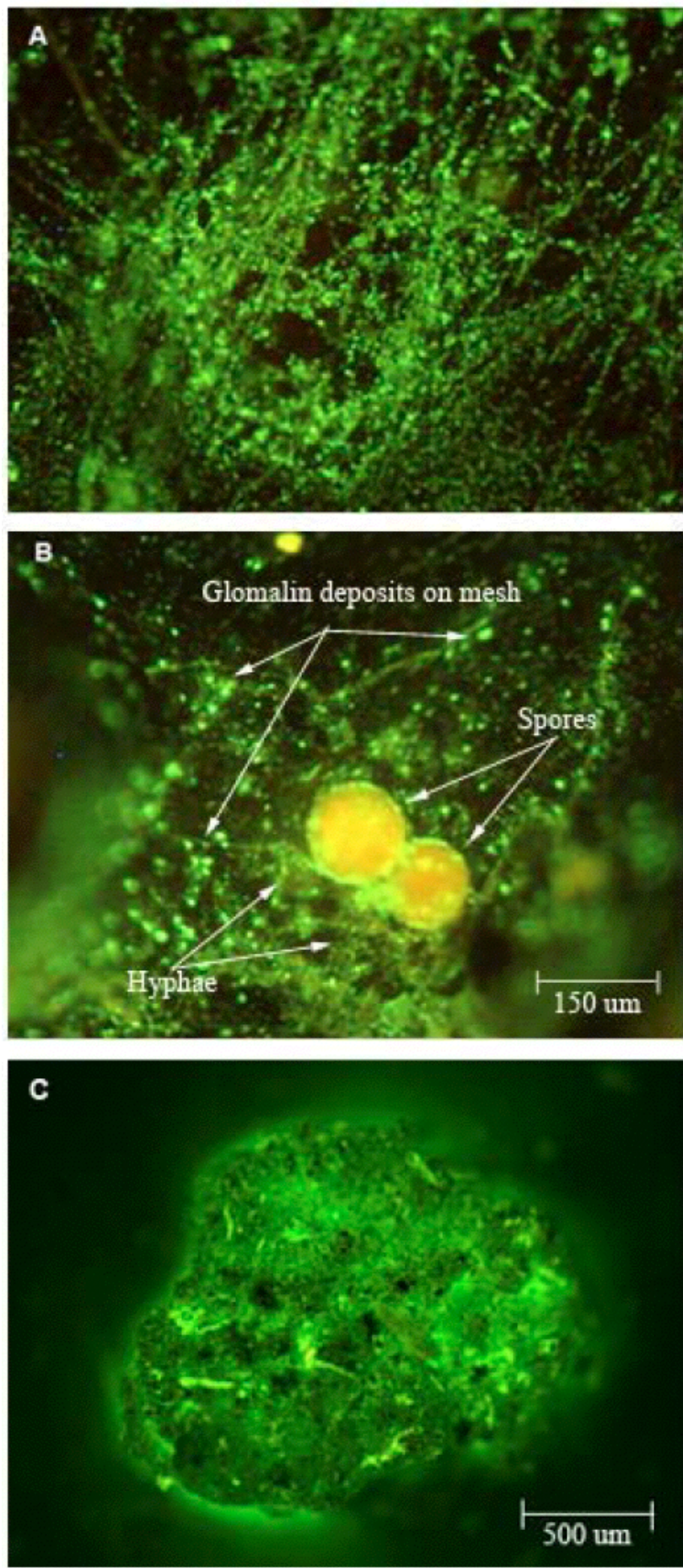

Fig. (4). The monoclonal antibody against glomalin is used in an immunofluresence assay to indicate where glomalin is located on fungal hyphae (A and B), Claroideoglomus etunicathum spores (B), and a $1 \mathrm{~mm}$ soil aggregate $(\mathbf{C})$ by binding to glomallin and then binding to an IgM antibody conjugated to fluorescein isothiocyanate which glows green under blue light.

hyphae and float on water films [46, 68]. Immunofluorescence indicates glomalin will self-aggregate on surfaces into plaque- or rodlike structures (Fig. 4) [46] similar to those structures formed by hydrophobins $[43,51]$.

Bacteria proliferate in the rhizosphere, especially near root cap cells where readily decomposable $\mathrm{C}$ is available and is used to produce bacterial EPS which form biofilms with strong adhesive properties enabling them to anchor to mineral surfaces [26, 69]. Substrate availability dictates spatial distribution of bacteria, especially in microaggregates, and limits colony size, while proximity to pore space may also impact the location of substrates and gas exchange [23, 6971]. Concentrations of bacterially-produced signal molecules suggest inter- and intra-species competition which can keep colony size small and inhibit the growth of other species. Because colony size is limited by these factors, the production of enough EPS to form biofilms would be limited [26]. Therefore, despite their importance in microaggregate formation and stabilization [69], bacterially-produced EPS biomolecules and biofilms would have a limited role in macroaggregate formation and stabilization due to high spatial variation [26].

\section{CHEMICAL REACTIONS}

Chemical reactions involve ionic and electrostatic bonds as well as attractive and repulsive forces (or van der Waals forces) [32]. These bonds may occur on the atomic or molecular levels and may have the strength to increase aggregate stability. Clay minerals and OM have both negative and positive surfaces which means they may create stable, ionic bonds between themselves and each other to stabilize aggregates $[11,48,70]$. Polysaccharides may be found within the three-layer lattice structure of clays [8]. Clay skins or coatings consist of clay minerals oriented in such a way that they can bind with occluded coarser material such as OM or metals, particularly Fe. Water movement distributes clay skins throughout the soil, and they precipitate with drying and act as nuclei for aggregate formation [8, 23]. Ionic bonds also may form between polyvalent cations; including iron, calcium, magnesium, and zinc; clay minerals and OM to create organo-mineral complexes [7]. When in these complexes, individual soil particles are more likely to get caught in root and fungal 'bags' $[11,12]$ and labile OM becomes more resistant to decomposition $[6,69,70]$. Soluble compounds, such as, carbonates, and OM, are concentrated in the liquid phase. As soils dry, these compounds precipitate as inorganic semi-crystalline or amorphous compounds cemented together via hydrogen bonds.

Hydrogen bonds between hydrogen and hydroxyl ions are a weak form of ionic bonding which are susceptible to rapid enzymatic digestion unless molecules making up OM polymers are highly-branched, form multiple bonds, or differ in structure. The hydrogen bonds found in polymeric compounds, especially polysaccharides, are much weaker and more easily broken than ionic bonding in organo-mineral complexes. However, a branched, lower oxygen-containing, or protein-bound polymer, such as a biofilm, humic acid, or glycoprotein, has multiple hydrogen bonds to stabilize the molecular structure [21, 48, 67, 72].

Van der Waals forces are the attractive and repulsive forces between polar and non-polar molecules or parts of a molecule. Polar molecules, such as carbohydrates, are hydrophilic or water-soluble, while non-polar molecules, such as lipids, are hydrophobic or water-insoluble. Some molecules, such as lipo-polysaccharides or glycoproteins, contain both polar and non-polar ends. In the case of polarity, the hydrophobic end is more stable when contacted by a non- 

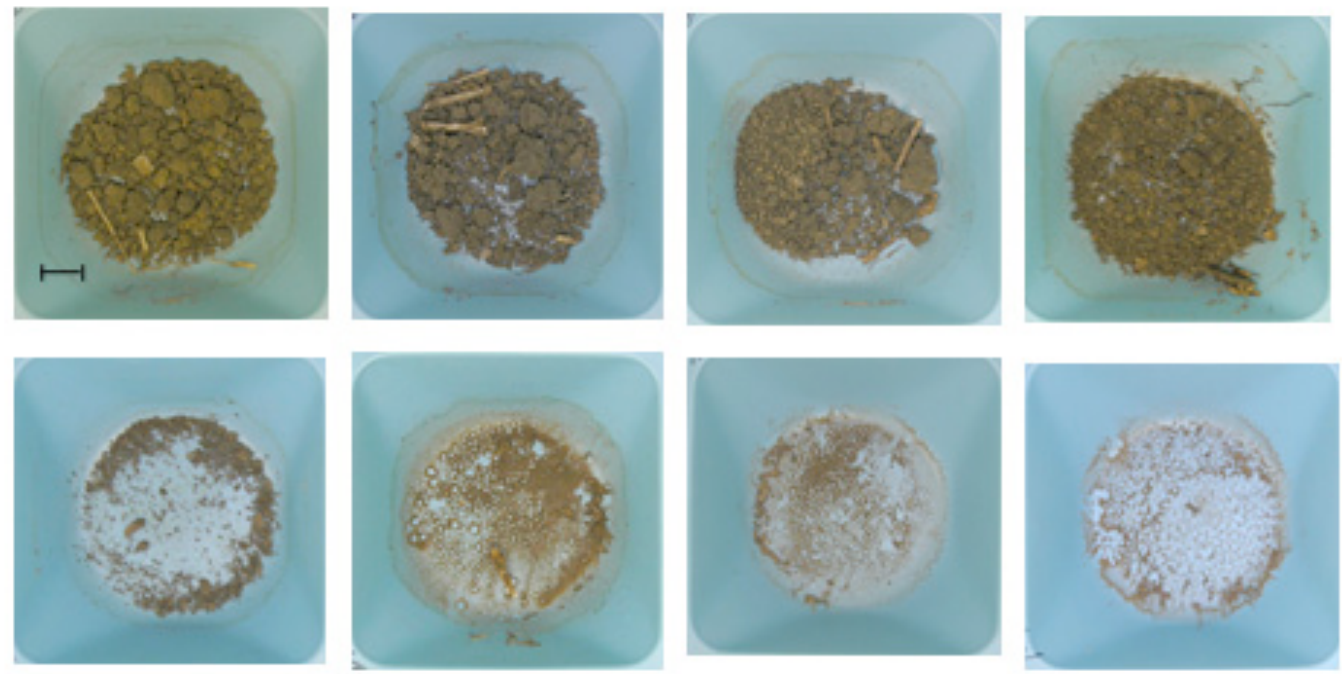

Fig. (5). Soil collected on top of the screen after one, two, three, or four (left to right) wet-dry cycles from an idle, perennial grassland (A) and a no-till, spring wheat (TriticumaestivumL.-fallow (chemical fallow) (B) sites. Both sites are on similar soil types - the grassland on a Belfield-Grail silty clay loam (fine, smectitic, frigid GlossicNatrustolls and fine, smectitic, frigid PachicVerticArgiustolls) and the no-till on a Temvik-Wilton silt loam soil (fine-silty, mixed, superactive, frigid Typic and PachicHaplustolls) - and are separated by about $2.5 \mathrm{~km}$. Scale bar is $9 \mathrm{~mm}$ and is the same across all pictures.

aqueous solution. Stability increases as contact angle for water penetration increases which restricts movement into intra-aggregate pores.

To stabilize a macroaggregate, the types of biomolecules discussed here should be plentiful on the surface of the aggregate or in pore spaces connected to the aggregate surface, thus preventing disruptive materials (i.e. air and water) from disrupting the aggregate. Polysaccharides, produced by bacteria, are not considered to be the main stabilizing agents, because of their weak bonds, and microscopic analysis shows a relatively high degree of variation in the spatial distribution of bacteria and biofilm formation [26].

\section{PHYSICAL FORCES}

The physical forces involved in macroaggregation include wet-dry and freeze-thaw cycles where soil shrinks and swells as well as torsion forces from root, earthworm, or other biological movement, or mechanical forces from tillage or vehicle or hoof traffic $[23,42]$. The translocation of soil components changes their spatial distribution and packing which may assist in macroaggregate formation or may disrupt aggregate stability depending upon if the distance between particles is increased or decreased. Physical forces also may act in aggregate stabilization by strengthening chemical bonds and forming planes of strength or weakness between soil components [42].

During wet-dry and freeze-thaw cycles, water is moving into and out of soil pores causing physical changes. Soil components may be physically transported on water films, or they may be held in place by surface tension at air-water interfaces or by cohesive tension between water molecules [21]. As soils dry or freeze, water is moving out of pore spaces which may deposit soil components in different locations or increase the chemical bond strength between organic molecules during their precipitation [42]. As the water itself freezes, the space between molecules increases and this expansion creates a mechanical force which physically changes the pore space. Water movement into dry soils may cause air-pressure to build and rupture an aggregate [21, 44]. Air molecules do not dissolve quickly into liquids [32]. For example, oxygen gas moves $10^{4}$ times faster in air than in water [73]. When water enters intra-aggregate pores, water molecules displace trapped air molecules, forcing them together and building pressure until an explosive release occurs.

Soil shrinking and swelling occurs when water molecules enter or leave the lattice structure of clay minerals.Clay minerals expand or swell when water enters the lattice and then collapse or shrink when water molecules are extracted [8, 22]. Shrinking and swelling depend on the type and concentrations of clay minerals. For example, double-layer clay minerals such as montmorillinite have two layers of lattice structures and have a greater shrink-swell capacity than single-layer clays such as kaolinite. Both shrinking and swelling may assist in either decreasing or increasing the distance between soil components which impacts both aggregate formation and disruption [7, 19, 27, 48]. Sometimes, soil components may be pulled together during shrinking or pushed together during swelling, while in other cases cracks may form.

In one study, ten wetting and drying cycles were performed on soils amended with bacterial or root polysaccharides [33]. Porosity increased with each wetting and drying cycle, but when root polysaccharides were added, tensile strength increased more than porosity. In a similar study using only four wet-dry cycles, preliminary results showed that an untilled pasture had the highest levels of water-stable aggregates compared to no or minimum tilled cropped fields and a tilled-fallow site but for each individual site, the greatest loss in aggregate stability occurred after the first cycle (Nichols, unpublished data) (Fig. 5). These studies indicate that biological activities and chemical reactions are integrated with physical forces.

As roots, earthworms, and other soil biota move through soil, physical forces are created which change the distribution of soil components. Torsion forces from the axial pres- 
sure on the surrounding soil created as roots and fungal hyphae grow or soil macrofauna, such as earthworms and insects, moving throughout the soil may compress components together while radial pressure may form cracks $[6,23,33$, $34,42]$. Similarly, mechanical forces from tillage or vehicle or hoof traffic may assist in both aggregate formation and destabilization where compression or compaction brings soil components closer together or forms cracks within aggregates $[6,74]$.

\section{IMPACT OF ABOVEGROUND MANAGEMENT ON MACROAGGREGATION}

Microbial communities regulate OM decomposition and nutrient cycling and are influenced by primary productivity, plant litter quality, climate, topography, and parent material, and agricultural practices such as tillage, synthetic fertilizer use, pesticide use, and grazing [75]. Macroaggregates create soils with well-defined crumb structures that have larger pores, faster water infiltration, and better gas movement. Soils containing high proportions of stable macroaggregates have undergone less physical disturbance from tillage or hoof traffic and OM decomposition than soils dominated by microaggregates [23]. Agricultural management practices that promote the formation and stabilization of soil aggregates are: (a) reduction in tillage; (b) increasing plant growth biomass and duration, diversity, and exudates; (c) increasing surface residue; (d) decreasing the use of inorganic fertilizer and pesticides; and (e) sustainable grazing management.

Aggregate disruption by cultivation can decrease soil water infiltration and fertility and increase erosion [19]. Several studies have shown that changes in the frequency and intensity of tillage practices alter carbon accumulation and soil aggregation [76]. As tillage intensity increases, carbon loss accelerates due to increased oxygenation and respiration and movement of rapid decomposers to subsurface soil [73]. No-till management and rooting patterns encouraged by notill promote aggregation and availability of $\mathrm{C}[8,24,69]$. If macromolecular $\mathrm{C}$ compounds are not protected from decomposition, they must be continuously replaced to maintain aggregate stability. Tillage breaks up soil clods, and causes roots to lyse and disrupt aggregates [24, 69]. Arbuscular mycorrhizae and saprophytic fungi are disrupted by tillage, but once tillage ends and substrate becomes available, these fungi may rapidly increase [77]. Tillage also alters microbial community structure and promotes bacteria over fungi which means there are few hyphal networks to enmesh soil into macroaggregates and more labile polysaccharides than fungal biomolecules [73]. Keeping fields green and growing longer provide a continuous input of new $\mathrm{C}$ to replace labile $\mathrm{C}$ in aggregates [7]. Studies have found that in systems with continuous cropping rather than crop-fallow rotations, microbial biomass increases [78, 79]. Residue which is higher in $\mathrm{N}$ content, such as that from legumes, may be subjected to more rapid decomposition and will reduce the amount of basidiomycete russuloid fungal growth, which may reduce soil aggregation [74]. However, N-rich residue has been found to increase uronic-acid and glomalin production which may influence long-term soil aggregate stability [64, 74].

On a macroaggregate scale, above ground management may influence aggregate formation and stabilization, not just from physical forces of tillage or hoof traffic, but also with respect to the energy requirements for the biochemical processes [62]. Active microbes use photosynthetically-derived C to grow and produce enzymes [24, 40,80]. Oades [6] lists three things that are required for aggregate stabilization: (a) photosynthetically-derived $\mathrm{C}$ as an energy source directly or indirectly drives all biological activity; (b) where this $\mathrm{C}$ is deposited (i.e. in surface litter, large roots, fine roots, or root exudates) and how available it is for decomposition; and (c) how well soil conditions support biological growth. The initial decomposition of OM is correlated with chemical composition, particularly the $\mathrm{C}: \mathrm{N}$ ratio, and spatial and temporal availability $[29,29]$. Decomposition of other OM constituents may require co-metabolism processes with multiple organisms or mechanisms around microenvironmental conditions that restrict enzyme access or activity, such as hydrophobicity, sorption to surfaces, or the pore exclusion principle $[26,73]$. Therefore, the composition and sorptive capacity of OM have impacts on what roles it will play in forming or stabilizing aggregates [29].

Under high application conditions, synthetic, fertilizers decrease populations of microbes directly dependent on plants, such as AM fungi. If a plant receives inorganic fertilizers, it becomes less dependent upon soil fertility generated by microbial activity and reduces the amount of belowground $\mathrm{C}$ deposition. This will tend to starve many organisms in the soil food web which are dependent either directly or indirectly upon root exudates for survival. Use of fungicides or insecticides also reduces the survival rates of many microbes by killing non-target species [53]. More stable macroaggregates are formed under monocots than dicots, grasses than cereals, and perennials than annuals [6, 24, 77].

Current research shows that POM may improve carbon storage since this labile organic matter becomes more stable and provides more organic matter for conversion into the 'humified' pool. Understanding that the meanings and roles of different SOM fractions in soil processes are changing as new research shows how rates of $\mathrm{C}$ turnover in the soil limit microbial growth and how the quality and availability of $\mathrm{C}$ for decomposition alters biogeochemical processes.

\section{SUMMARY}

To feed a growing global population and maintain ecosystem services, we must understand how a healthy soil is created. A systems approach to agriculture which incorporates sustainable intensification, renewable resources, and biologically-intensive nutrient and pest management tools must be developed [1,2]. The new 'green' revolution is a 'brown' revolution based on highly efficient soil biological synergies. Soil structure, which stems from macroaggregate size and distribution, is important to plant and soil health. It provides pore space for better water and gas movement for plant roots and microbes. Increased presence of macroaggregates makes soil more resistant to erosive forces, and their composition and stability help soils sequester carbon. Within macroaggregates, OM decomposition occurs at a slower rate than with free $\mathrm{OM}$, which provides more efficient nutrient cycling.

Macroaggregate formation and stabilization are extremely complex processes. In the soil environment, physical forces acting with chemical reactions and biological activities play multiple roles in aggregation and may depend upon 
soil conditions and microbial content. Although microaggregates are highly stable, their small size makes them susceptible to erosive forces from wind and rain. In contrast, macroaggregates are larger in size and are frequently less stable than microaggregates. In addition, cohesive forces which stabilize aggregates are more spatially distributed within aggregates or on their surfaces which may make the macroaggregate more susceptible to disruption over time [9, 71]. Examples of aggregate formation and stabilization processes are: (a) formation of organo-mineral complexes where ionic bonds are formed between $\mathrm{OM}$ and clay minerals, $\mathrm{OM}$ and polyvalent cations, and $\mathrm{OM}$, clay minerals and polyvalent cations; (b) clay minerals bound to each other; (c) OM fragments bound to each other; (d) bacterial polysaccharides which are linked together into long chains and may form biofilms, (e) fungal hyphae which provides the net to initiate aggregate formation, and (f) fungal biomolecules, such as glomalin and hydrophobins. Management practices, such as increased crop diversity, continuous cropping, cover crops, organic fertilizer use, and sustainable grazing, enhance microbial growth and production of biomolecules which enhance aggregate formation and stabilization.

\section{ABBREVIATIONS}

$\begin{array}{lll}\mathrm{ASC} & =\text { Aggregate Size Class } \\ \mathrm{AM} & = & \text { Arbuscular Mycorrhizal } \\ \mathrm{C} & = & \text { Carbon } \\ \mathrm{DASD} & = & \text { Dry Aggregate Size Distribution } \\ \mathrm{N} & = & \text { Nitrogen } \\ \mathrm{OM} & = & \text { Organic Matter } \\ \mathrm{POM} & = & \text { Particulate Organic Matter } \\ \mathrm{SOM} & = & \text { Soil Organic Matter } \\ \text { WSA } & = & \text { Water-Stable Aggregate } \\ \text { WSSI } & =\text { Whole Soil Stability Index }\end{array}$

\section{NONDISCRIMINATION STATEMENT}

The U.S. Department of Agriculture (USDA) prohibits discrimination in all its programs and activities on the basis of race, color, national origin, age, disability, and where applicable, sex, marital status, familial status, parental status, religion, sexual orientation, genetic information, political beliefs, reprisal, or because all or part of an individual's income is derived from any public assistance program. (Not all prohibited bases apply to all programs.) Persons with disabilities who require alternative means for communication of program information (Braille, large print, audiotape, etc.) should contact USDA's TARGET Center at (202) 720-2600 (voice and TDD). To file a complaint of discrimination, write to USDA, Director, Office of Civil Rights, 1400 Independence Avenue, S.W., Washington, D.C. 20250-9410, or call (800) 795-3272 (voice) or (202) 720-6382 (TDD). USDA is an equal opportunity provider and employer.

Mention of commercial products and organizations in this manuscript is solely to provide specific information. It does not constitute endorsement by USDA-ARS over other products and organizations not mentioned.

\section{CONFLICT OF INTEREST}

The authors confirm that this article content has no conflicts of interest.

\section{ACKNOWLEDGEMENTS}

The authors would like to acknowledge the invaluable comments provided by Dr. Francisco Calderon and Steve Merrill on earlier drafts of this manuscript. Laboratory assistance provided by Dawn Wetch, Ann Solano, Robert Haaland, and Tyler Malm provided data which contributed to these theories. In addition, discussions with ARS and nonARS colleagues on soil aggregation were important in this work.

\section{REFERENCES}

[1] Doran JW, Kirschenmann F, Magdoff FR. Editorial: Balancing food, environmental and resource needs. Renew Agric Food Syst 2008; 22(2): 77-79.

[2] Karlen DL, Andrews SS, Weinhold BJ, Doran JW. Soil quality: Humankind's foundation for survival. J Soil Water Conser 2003; 58(4): 171-179.

[3] Gregory PJ, Atkinson CJ, Bengough AG, et al. Contributions of roots and rootstocks to sustainable, intensified crop production. J Exp Bot 2013; 64(5): 1209-1222.

[4] Pretty J. Agricultual sustainability: Concepts, principles and evidence. Philos Trans R Soc B 2008; 363: 447-465.

[5] Carter MR. Soil quality for sustainable land management: Organic matter and aggregation interactions that maintain soil functions. Agron J 2002; 94: 38-47.

[6] Oades JM. The role of biology in the formation, stabilization, and degradation of soil structure. Geoderma 1993; 56: 377-400.

[7] Boyle M, Frankenberger WT Jr, Stolzy LH. The influence of organic matter on soil aggregation and water infiltration. J Prod Agric 1989; 2(4): 290-299.

[8] Allison FE. Soil Aggregation - Some facts and fallicies as seen by a microbiologist. Soil Sci 1968; 106(2): 136-143.

[9] Beare MH, Cabrera ML, Hendrix PF, Coleman DC. Aggregateprotected and unprotected organic matter pools in conventionaland no-tillage soils. Soil Sci Soc Am J 1994; 58 (3): 787-795.

[10] Tisdall JM, Oades JM. Organic matter and water-stable aggregates in soils. J Soil Sci 1982; 33: 141-163.

[11] Tisdall JM, Oades JM. Stabilization of soil aggregates by the root systems of ryegrass. Aust J Soil Res 1979; 17: 429-441.

[12] Miller RM, Reinhardt DR, Jastrow JD. External hyphal production of vesicular-arbuscular mycorrhizal fungi in pasture and tallgrass prairie communities. Oecologia 1995; 103: 17-23.

[13] Chaney K, Swift RS. Studies on aggregate stability. I. Reformation of soil aggregates. J Soil Sci 1986; 37: 329-335.

[14] Six J, Paustian K, Elliott ET, Combrink C. Soil structure and organic matter. I. Distribution of aggregate-size classes and aggregate-associated carbon. Soil Sci Soc Am J 2000; 64(2): 681-689.

[15] Gale WJ, Cambardella C, Bailey TB. Root-derived carbon and the formation and stabilization of aggregates. Soil Sci Soc Am J 2000; 64: 201-207.

[16] Six J, Elliott ET, Paustian K. Soil structure and soil organic matter: II. A normalized stability index and the effect of mineralogy. Soil Sci Soc Am J 2000; 64: 1042-1049.

[17] Nichols KA, Toro M. A whole soil stability index (WSSI) for evaluating soil aggregation. Soil Till Res 2011;111:99-104.

[18] Hammerbeck A, Stetson S, Osborne S, Schumacher TE, Pikul Jr. J. Impact of corm residue removal on soil aggregate distribution and properties. Soil Sci Soc Am J 2012; 76: 1390-1398.

[19] van Steenbergen M, Cambardella C, Elliott ET, Merckx R. Two simple indices for distributions of soil components among size classes. Agric Ecosyst Environ 1991; 34: 335-340.

[20] Stetson SJ, Osborne SL, Schumacher TE, Eynard A, Chilom G, Rice J, Nichols KA, Pikul Jr. JL. Corn residue removal impact on topsoil organic carbon in a corn-soybean rotation. Soil Sci Soc Am J 2012; 76: 1399-1406.

[21] Kemper WD, Rosenau RC. In: Klute A, Ed. Aggregate stability and size distribution. Methods of Soil Analysis, Part I. Physical and 
Mineralogical Methods, American Society of Agronomy-Soil Science Society of America, Madison, WI 1986; pp. 425-442.

[22] Allison SD, Jastrow JD. Activities of extracellular enzymes in physically isolated fractions of restored grassland soils. Soil Biol Biochem 2006; 38: 3245-3256.

[23] Six J, Bossuyt H, Degryze S, Denef K. A history of research on the link between (micro)aggregates, soil biota, and soil organic matter dynamics. Soil Till Res 2004; 79: 7-31.

[24] Haynes RJ, Beare MH. Influence of six crop species on aggregate stability and some labile organic matter fractions. Soil Biol Biochem 1997; 29 (11/12): 1647-1653.

[25] Abiven S, Menasseri S, Chenu C. The effects of organic inputs over time on soil aggregate stability - A literature analysis. Soil Biol Biochem 2009; 41: 1-12.

[26] Nunan N, Wu K, Young IM, Crawford JW, Ritz K. Spatial distribution of bacterial communities and their relationships with the micro-architecture of soil. FEMS Microbiol Ecol 2003; 44(2): 203215.

[27] Denef K, Six J, Paustian K, Merckx R. Importance of macroaggregate dynamics in controlling soil carbon stabilization: short-term effects of physical disturbance induced by dry-wet cycles. Soil Biol Biochem 2001; 33 (15): 2145-2153.

[28] Six J, Frey SD, Thiet RK, Batten KM. Bacterial and fungal contributions to carbon sequestration in agroecosystems. Soil Sci Soc Am J 2006; 70(2): 555-569.

[29] Schmidt MWI, Torn MS, Abiven S, Dittmar T, Guggenberger G, Janssens IA, Kleber M, Kogel-Knabner I, Lehmann J, Manning DAC, Nannipieri P, Rasse DP, Weinger S, Tsadilas CD. Persistence of soil organic matter as an ecosystem propoerty. Nature 2011; 478: 49-56.

[30] Liao JD, Boutton TW, Jastrow JD. Organic matter turnover in soil physical fractions following woody plant invasion of grassland: Evidence from natural 13C and 15N. Soil Biol Biochem 2006; 38: 3197-3210.

[31] Angers DA, Giroux M. Recently deposited organic matter in soil water-stable aggregates. Soil Sci Soc Am J 1996; 60(5): 15471551.

[32] McQuarrie DA, Rock PA. General Chemistry, W.H. Freeman and Co., New York 1987; pp. 1-876.

[33] Czarnes S, Hallett PD, Bengough AG, Young IM. Root- and microbial-derived mucilages affect soil structure and water transport. Eur J Soil Sci 2000; 51: 435-443.

[34] Davidson DA, Bruneau PMC, Grieve IC, Young IM. Impacts of fauna on an upland grassland soil as determined by micromorphological analysis. Appl Soil Ecol 2002; 20(2): 133-143.

[35] Gensel PG, Andrews HN. The evolution of early land plants. Am Sci 1987; 75: 478-489.

[36] Taylor TN. Fungal associations in the terrestrial paleoecosystem. Trends Ecol Evol 1990; 5: 21-25.

[37] Hass H, Taylor TN, Remy W. Fungi from the Lower Devonian Rhynie Chert: mycoparasitism. Am J Bot 1994; 81(1): 29-37.

[38] Kirshner RP. The earth's elements. Sci Am 1994; 271: 59-65.

[39] Estes JA, Terborgh J, Brashares S, et al. Trophic downgrading of planet Earth. Science 2011; 333: 301-306.

[40] Caesar-TonThat TC, Cochran VL. Soil aggregate stabilization by a saprophytic lignin-decomposing basidiomycete fungus. I. Microbiological aspects. Biol Fertil Soils 2000; 32: 374-380.

[41] Cambardella CA, Elliott ET. Carbon and nitrogen dynamics of soil organic matter fractions from cultivated grassland soils. Soil Sci Soc Am J 1994; 58(1): 123-130.

[42] Young IM. Biophysical interactions at the root-soil interface: a review. J Agric Sci 1998; 130: 1-7.

[43] Wessels JGH. Hydrophobins: Proteins that change the nature of the fungal surface. Adv Micro Physiol 1997; 38: 1-45.

[44] Nichols KA, Wright SF. In: Magdoff FR, Weil RR, Eds. Contributions of soil fungi to organic matter in agricultural soils. Soil Organic Matter in Sustainable Agriculture. CRC Press: New York 2004; pp. 179-198.

[45] Caesar-TonThat TC. Soil binding properties of mucilage produced by a basidiomycete fungus in a model system. Mycolog Res 2002; 106(8): 930-937.

[46] Wright SF. A fluorescent antibody assay for hyphae and glomalin from arbuscular mycorrhizal fungi. Plant Soil 2000; 226(2): 171177.

[47] Azcon-Aguilar C, Gianinazzi-Pearson V, Fardeau JC, Gianinazzi S. Effect of vesicular-arbuscular mycorrhizal fungi and phosphate- solubilizing bacteria on growth and nutrition of soybean in a neutral-calcareous soil amended with 32P-45Ca-tricalcium phosphate. Plant Soil 1986; 96: 3-15.

[48] Chenu C, Le Bissonnais Y, Arrouays D. Organic matter influence on clay wettability and soil aggregate stability. Soil Sci Soc Am J 2000; 64: 1479-1486.

[49] Chenu C. Influence of a fungal polysaccharide, scleroglucan, on clay microstructure. Soil Biol Biochem 1989; 21(2): 299-305

[50] Wosten HAB. Hydrophobins: Multipurpose proteins. Annu Rev Microbiol 2001; 55: 625-646.

[51] Kwan AHY, Winefield RD, Sunde M, Matthews JM, Haverkamp RG, Templeton MD, Mackay JP. Structural basis for rodlet assembly in fungal hydrophobins. Proc Natl Acad Sci USA 2006; 103(10): 3621-3626.

[52] Kershaw MJ, Talbot NJ. Hydrophobins and repellents: proteins with fundamental roles in fungl morphogenesis. Fungal Genet Biol 2007; 23: 18-33.

[53] Beare MH, Hu S, Coleman DC, Hendrix PF. Influences of mycelial fungi on soil aggregation and organic matter storage in conventional and no-tillage soils. Appl Soil Ecol 1997; 5: 211-219.

[54] Wright SF, Franke-Snyder M, Morton JB, Upadhyaya A. Timecourse study and partial characterization of a protein on hyphae of arbuscular mycorrhizal fungi during active colonization of roots. Plant Soil 1996; 181: 193-203.

[55] Driver JD, Holben WE, Rillig MC. Characterization of glomalin as a hyphal wall component of arbuscular mycorrhizal fungi. Soil Biol Biochem 2005; 37(1): 101-106.

[56] Purin S, Rillig MC. Immuno-cytolocation of glomalin in the mycelium of the arbuscular mycorrhizal fungus Glomus intraradices Soil Biol Biochem 2008; (40): 1000-1003.

[57] Gadkar V, Rillig MC. The arbuscular mycorrhizal fungal protein glomalin is a putative homolog of heat shock protein 60 . FEMS Microbiol Ecol 2006; 263(1): 93-101.

[58] Purin S, Rillig MC. The arbucular mycorrhizal fungal protein glomalin: Limitation, progress, and a new hypothesis for its function. Pedobiol 2007; (51): 123-130.

[59] Wright SF, Nichols KA, Schmidt WF. Comparison of efficacy of three extractants to solubilize glomalin on hyphae and in soil. Chemosphere 2006; 64: 1219-1224.

[60] Rillig MC, Steinberg PD. Glomalin production by an arbuscular mycorrhizal fungus: a mechanism of habitat modification? Soil Biol Biochem 2002; 34 (9): 1371-1374.

[61] Rillig MC. Arbuscular mycorrhizae, glomalin, and soil aggregation. Can J Soil Sci 2004; 84(4): 355-363.

[62] Treseder KK, Turner KM. Glomalin in ecosystems. Soil Sci Soc Am J 2007; 71(4): 1257-1266.

[63] Wright S, Green VS, Cavigelli MA. Glomalin in aggregate size classes from three different farming systems. Soil Till Res 2007 94: 546-549.

[64] Wright SF, Upadhyaya A. A survey of soils for aggregate stability and glomalin, a glycoprotein produced by hyphae of arbuscular mycorrhizal fungi. Plant Soil 1998; 198(1): 97-107.

[65] Varki A. Biological roles of oligosaccharides: all of the theories are correct. Glycobiology 1993; 3(2): 97-130.

[66] Rillig MC, Wright SF, Nichols KA, Schmidt WF, Torn MS. Large contribution of arbuscular mycorrhizal fungi to soil carbon pools in tropical forest soils. Plant Soil 2001;233(2): 167-177.

[67] Piccolo A, Mbagwu JSC. Role of hydrophobic components of soil organic matter in soil aggregate stability. Soil Sci Soc Am J 1999; 63: $1801-1810$

[68] Wright SF, Upadhyaya A. Extraction of an abundant and unusual protein from soil and comparison with hyphal protein of arbuscular mycorrhizal fungi. Soil Sci 1996; 161(9): 575-586.

[69] Caesar-TonThat TC, Caesar AJ, Gaskin JF, Sainju UM, Busscher WJ. Taxonomic diversity of predominant culturable bacteria associated with microaggregates from two different agroecosystems and their ability to aggregate soil in vitro. Appl Soil Ecol 2007; 36(1): 10-21.

[70] Bossuyt H, Six J, Hendrix PF. Protection of soil carbon by microaggregates within earthworm casts. Soil Biol Biochem 2005; 37(2): 251-258.

[71] Oades JM, Waters AG. Aggregate hierarchy in soils. Aust J Soil Res 1991; 29: 815-828.

[72] Degens BP. Macro-aggregation of soils by biological bonding and binding mechanisms and the factors affecting these: a review. Aust J Soil Res 1997; 35: 431-459. 
[73] Young IM, Ritz K. Tillage, habitat space and function of soil microbes. Soil Till Res 2000; 53(3-4): 201-213.

[74] Caesar-TonThat TC, Sainju UM, Wright SF, Shelver WL, Kolberg RL, West M. Long-term tillage and cropping effects on microbiological properties associated with aggregation in a semi-arid soil. Biol Fertil Soils 2011; 47: 157-165.

[75] Karlen DL, Eash NS, Unger PW. Soil and crop management effects on soil quality indicators. Am J Alter Ag 1992; 7(1-2): 48-55.

[76] Amado TJC, Bayer C, Conceicao PC, Spagnollo E, Campos BHC, Veiga Md. Potential of carbon accumulation in no-till soils with intensive use and cover crops in Southern Brazil. J Environ Qual 2006; 35(4): 1599-1607.
[77] Allison VJ, Miller RM, Jastrow JD, Matamala R, Zak DR. Changes in soil microbical community structure in a tallgrass prairie chronosequence. Soil Sci Soc Am J 2005; 69: 1412-1421.

[78] Angers DA, Recous S, Aita C. Fate of carbon and nitrogen in water-stable aggregates during decomposition of ${ }^{13} \mathrm{C}^{15} \mathrm{~N}$-labelled wheat straw in situ. Eur J Soil Sci 1997; 48: 295-300.

[79] Bauer A, Black AL. Soil carbon, nitrogen, and bulk density comparisons in two cropland tillage systems after 25 years and in virgin grassland. Soil Sci Soc Am J 1981; 45: 1166-1170.

[80] Cambardella C, Elliott ET. Particulate soil organic-matter changes across a grassland cultivation sequence. Soil Sci Soc Am J 1992; 56: 777-783.

[81] Niewczas J, Witkowska-Walczak B. The soil aggregates stability index (ASI) and its extreme values. Soil Till Res 2005; 80: 69-78.

Received: June 01, 2013

(C) Nichols and Halvorson; Licensee Bentham Open.

This is an open access article licensed under the terms of the Creative Commons Attribution Non-Commercial License (http:/creativecommons.org/licenses/by-nc/3.0/) which permits unrestricted, non-commercial use, distribution and reproduction in any medium, provided the work is properly cited. 